\title{
COVER PLANTS AND MINERAL NITROGEN: EFFECTS ON ORGANIC MATTER FRACTIONS IN AN OXISOL UNDER NO- TILLAGE IN THE CERRADO(1)
}

\author{
${\text { Isis Lima dos } \text { Santos }^{(2)} \text {, Carla Ferreira Caixeta }}^{(2)}$, Alex Antônio Torres Cortês de Sousa ${ }^{(2)}$,

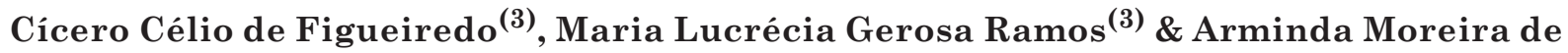 \\ Carvalho $^{(4)}$
}

\begin{abstract}
SUMMARY
Cover plants are essential for the sustainability of no-tillage systems in tropical regions. However, information on the effects of these plants and $\mathrm{N}$ fertilization on soil organic matter fractions is still scarce. This study evaluated the effect of cover crops with different chemical composition and of $\mathrm{N}$ topdressing on the labile and humified organic matter fractions of an Oxisol of the Cerrado (savanna-like vegetation). The study in a randomized complete block design was arranged in split-plots with three replications. Four cover species were tested in the plots and the presence or absence of $\mathrm{N}$ topdressing in the subplot. The following cover species were planted in succession to corn for eight years: Urochloa ruziziensis; Canavalia brasiliensis M. ex Benth; Cajanus cajan (L.) Millsp; and Sorghum bicolor (L.) Moench. In general, the cultivation of $U$. ruziziensis increased soil $\mathrm{C}$ levels, particularly of $\mathrm{C}$ in the humic acid and particulate organic $\mathrm{C}$ fractions, which are quality indicators of soil organic matter. The $\mathrm{C}$ in humic substances and mineral organic $\mathrm{C}$ accounted for the highest proportions of total organic $\mathrm{C}$, demonstrating the strong interaction between organic matter, Fe and Al oxides and kaolinite, which are predominant in these weathered soils of the Cerrado.
\end{abstract}

Index terms: organic carbon, humic substances, particulate organic carbon.

(1) Received for publication on January 21, 2014 and approved on August 28, 2014.

(2) Student of the Post Graduate Course in Agronomy, Faculdade de Agronomia e Medicina Veterinária, Universidade de Brasília - UnB. Caixa Postal 04508. CEP 70910-970 Brasília (DF), Brazil. E-mail: isis.lima21@bol.com.br, carlaferreiracaixeta@gmail.com, acagrocerrado@gmail.com

(3) Professor, Faculdade de Agronomia e Medicina Veterinária, UnB. E-mail: cicerocf@unb.br, lucrecia@unb.br

(4) Researcher, Embrapa Cerrados. BR 020, km 18. Caixa Postal 08223. CEP 73310-970 Planaltina (DF), Brazil. E-mail: arminda.carvalho@embrapa.br 


\title{
RESUMO: PLANTAS DE COBERTURA E NITROGÊEIO MINERAL: EFEITOS NAS FRAÇÕES DA MATÉRIA ORGÂNICA DE LATOSSOLO SOB PLANTIO DIRETO NO CERRADO
}

\begin{abstract}
Plantas de coberturas são fundamentais para sustentabilidade do sistema de plantio direto em regiões tropicais. No entanto, ainda há pouca informação sobre os efeitos dessas plantas e da adubação nitrogenada sobre as frações da matéria orgânica do solo. O objetivo deste trabalho foi avaliar o efeito de plantas de cobertura com composição química diferenciada e da aplicação de $N$ em cobertura nas frações lábeis e humificadas da matéria orgânica de um Latossolo sob plantio direto no Cerrado. O estudo foi realizado em delineamento de blocos ao acaso, com parcelas divididas e três repetições. Foram utilizadas quatro plantas de cobertura nas parcelas e presença ou ausência de fertilização nitrogenada em cobertura na subparcela. As seguintes plantas de cobertura foram utilizadas em sucessão ao milho, por oito anos: Urochloa ruziziensis; Canavalia brasiliensis M. ex Benth; Cajanus cajan (L.) Millsp; $e$ Sorghum bicolor (L.) Moench. Em geral, o uso da U. ruziziensis resultou nos maiores teores de C no solo com destaque para o C nas frações ácido húmico e C orgânico particulado, que são indicadores da qualidade da matéria orgânica do solo. $O$ C das substâncias húmicas e o $C$ orgânico associados aos minerais apresentaram as maiores proporções do Corgânico totale demonstraram a forte interação da matéria orgânica com os óxidos de Fe e Al e a caulinita, que predominam nesses solos intemperizados do Cerrado.
\end{abstract}

Termos de indexação: carbono orgânico, substâncias húmicas, carbono orgânico particulado.

\section{INTRODUCTION}

Soil organic matter (SOM) is one of the most commonly used indicators of soil quality, responsible for essential functions of soil sustainability, especially in highly weathered soil, for example the predominant Oxisols of the Brazilian Cerrado. This property is also relevant in the context of climate change, since the soil is the largest $\mathrm{C}$ reservoir on the Earth's surface (Alves et al., 2006). In the Cerrado region, the conversion of natural to agricultural systems usually leads to reductions in the SOM contents (Figueiredo et al., 2013). In this context, no-tillage associated with cover crops is an alternative to increase soil organic carbon (SOC) accumulation, as a contribution to a sustainable grain production in the Cerrado, maintaining soil quality and reducing greenhouse gas emissions (Salton et al., 2011; Carvalho et al., 2012; Rossi et al., 2012).

Planting grasses and legumes as ground cover crops in no-tillage (NT) systems is one of the most promising management practices for nutrient maintenance and cycling and for changes in the dynamics and accumulation of organic soil fractions. Legumes, for example, are planted for their $\mathrm{N}$ input to the soil and their deep roots that absorb nutrients in soil layers below the root zone of annual crops (Loss et al., 2009), and transfer them to the soil surface in the form of plant residues. On the other hand, grasses with a deep root system and high biomass production are essential for nutrient supply in the long term, mainly in the soil surface layers. However, the most decisive factor in the decomposition of plant organic material is the chemical composition. The participation of $\mathrm{N}$ and organic compounds such as lignin, cellulose and hemicellulose regulate the decomposition rate of plant residues, by increasing or reducing this process (Carvalho et al., 2011; 2012), with effects on the accumulation of SOM fractions.

Aside from knowledge about the chemical composition of cover species involved in the production systems, it is important to identify which and in which proportions the organic fractions are being formed, as well as to assess the effect of $\mathrm{N}$ fertilizers on the accumulation of these fractions.

In assessments of soil use and management, SOM is quantified by determining total organic carbon (TOC), although the quantification of this property provides little information on the overall dynamics of soil C (Figueiredo et al., 2013). Vergutz et al. (2010) reinforced that not only TOC, but also SOM fractionation is necessary, which can increase sensitivity to differentiate soils under different uses and management (Bayer et al., 2002). Among these are fractions of higher lability, such as labile and particulate carbon (POC) and the more recalcitrant, such as organic carbon associated to minerals (MOC) and humic substances such as humic acid (HA-C), fulvic (FA-C) and humin acid (HUM-C).

Due to the greater lability in POC stocks, the fraction is sensitive to management practices and changes are usually detectable in the short term (Bayer et al., 2002; Figueiredo et al., 2010; Figueiredo et al., 2013). Readily available labile $\mathrm{C}$ can also be cited as one of the management-sensitive fractions. Significant variations in their contents can be observed by the use of certain cover species with less lignin and rapid decomposition. The humic substances, which are more stable, consist of complex and heterogeneous molecules and have been used as soil quality indicators due to their strong interaction with the mineral soil material (Fontana et al., 2006). 
In view of the need to identify plant species for the formation of crop residues that contribute to the soil quality in tropical regions, this study evaluated the effect of cover species with differentiated chemical composition and fertilized with $\mathrm{N}$ topdressing on SOC and its fractions in an Oxisol under no-tillage corn in the Cerrado.

\section{MATERIAL AND METHODS}

\section{Location and characteristics of the experimental area}

An experiment with soybean/corn rotation was initiated in 1999 at Embrapa Cerrado, Planaltina, DF (latitude $15^{\circ} 35^{\prime} 30^{\prime \prime} \mathrm{S}$, longitude $47^{\circ} 42^{\prime} 30^{\prime \prime} \mathrm{W}$ ). In 2005 , a succession of cover plants/no-tillage corn was planted in the area. Corn was grown immediately after harvesting the cover crops, which were always sown at the end of the rainy season (second fortnight of March).

The soil was classified as a clayey Oxisol of the Cerrado, with a plain relief. By the soil chemical analysis (layer $0-10 \mathrm{~cm}$ ) at the beginning of the experiment in February 2005, the following properties were determined as proposed by Embrapa (1997): $\mathrm{pH}\left(\mathrm{H}_{2} \mathrm{O}\right)=6.0 ; \mathrm{OM}=21.7 \mathrm{~g} \mathrm{~kg}^{-1} ; \mathrm{P}_{\text {Mehlich-1 }}=0.9 \mathrm{mg} \mathrm{kg}^{-1}$; $\mathrm{Al}^{3+}=0.1 \mathrm{cmol}_{\mathrm{c}} \mathrm{kg}^{-1} ; \mathrm{Ca}^{2+}+\mathrm{Mg}^{2+}=2.9 \mathrm{cmol}_{\mathrm{c}} \mathrm{kg}^{-1} ; \mathrm{K}^{+}=0.1$ $\mathrm{cmol}_{\mathrm{c}} \mathrm{kg}^{-1}$. The mineralogical composition of the diagnostic horizon of the study soil consisted of: kaolinite $\left(320 \mathrm{~g} \mathrm{~kg}^{-1}\right)$; gibbsite $\left(496 \mathrm{~g} \mathrm{~kg}^{-1}\right)$; hematite $\left(142 \mathrm{~g} \mathrm{~kg}^{-1}\right)$; and goethite $\left(42 \mathrm{~g} \mathrm{~kg}^{-1}\right)$, as described by Reatto et al. (2009).

According to Köppen, the local climate is classified as tropical seasonal (Aw), with rainy summers. The mean annual rainfall in the region ranges from 1,400 to $1,600 \mathrm{~mm}$, with a mean annual temperatur e of $24.5^{\circ} \mathrm{C}$ (Adámoli et al., 1986). Figure 1 shows the mean monthly precipitation and temperatures from

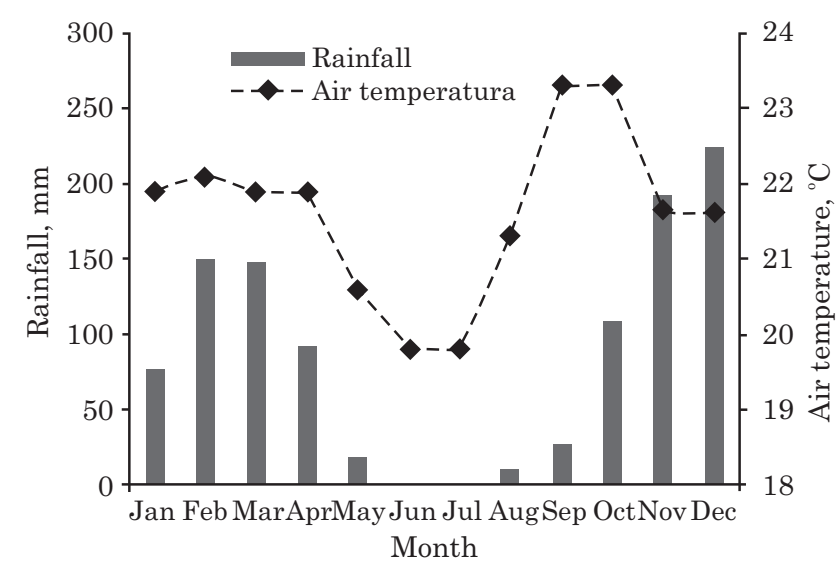

Figure 1. Mean monthly rainfall and mean air temperature from 2005 to 2013 , in the experimental area of Embrapa Cerrados, Planaltina, DF. the beginning of the experiment in 2005 until sampling in 2013.

The experiment was arranged in a randomized block, split-plot design with three replications. The plots consisted of cover species and subplots of $\mathrm{N}$ fertilization $\left(130 \mathrm{~kg} \mathrm{ha}^{-1} \mathrm{~N}\right.$ divided in two applications of $65 \mathrm{~kg} \mathrm{ha}^{-1} \mathrm{~N}$; and without fertilization).

The following cover species were sown in the first week of April (end of the rainy season): Urochloa ruziziensis Germain and Evrard, Poaceae; Canavalia brasiliensis Mart. ex Benth, Fabaceae; pigeonpea (Cajanus cajan (L.) Millsp, Fabaceae); and sorghum (Sorghum bicolor (L.) Moench, Poaceae). The plant density was 20 plants $\mathrm{m}^{-1}$ for C. cajan, S. bicolor and $U$. ruziziensis; and 10 plants $\mathrm{m}^{-1}$ for $C$. brasiliensis. The spacing between plant rows was $0.5 \mathrm{~m}$ for all plant species (Carvalho \& Amabile, 2006).

The cover crops were sown directly on the residues of the preceding corn crop, exploiting the residual fertility. Later, they were mowed at flowering. Maize was sown in the first week of November 2012. Fertilization was applied in the planting furrow, consisting of: $20 \mathrm{~kg} \mathrm{ha}^{-1} \mathrm{~N}$ (urea), $150 \mathrm{~kg} \mathrm{ha}^{-1} \mathrm{P}_{2} \mathrm{O}_{5}$ (triple superphosphate) and $80 \mathrm{~kg} \mathrm{ha}^{-1} \mathrm{~K}_{2} \mathrm{O}$ (potassium chloride). Topdressing was applied in two rates of $75 \mathrm{~kg} \mathrm{ha}^{-1}$, the first when corn plants developed the fourth pair of leaves and the second when the eighth pair appeared, together a total of $170 \mathrm{~kg} \mathrm{ha}^{-1} \mathrm{~N}$, when considering $\mathrm{N}$ applied at sowing and topdressing.

The mean hemicellulose, cellulose and lignin concentrations at flowering and maturation in the aerial parts of the cover plants evaluated in this study were determined by the sequential extraction method of Robertson \& van Soest (1981), and presented in table 1.

\section{Soil sampling and analysis}

Soil samples were collected from the layers 0.0-0.10 and 0.10-0.20 $\mathrm{m}$ at the end of the crop cycle, forming one composite sample of each five subsamples. After collection, samples were sent to the Laboratory of Soil Organic Matter at the University of Brasília, air-dried and sieved $(<2 \mathrm{~mm})$.

Total organic carbon (TOC) was determined by wet oxidation with potassium dichromate in the presence

Table 1. Concentration of hemicellulose, cellulose and lignin in aerial parts of the cover plants (mean concentrations at flowering and maturatity cuts)

\begin{tabular}{lccc}
\hline Cover specie & Hemicellulose & Cellulose & Lignin \\
\cline { 2 - 4 } & & g kg$^{-1}$ & \\
C. cajan & 160.6 & 105.8 & 59.5 \\
C. brasiliensis & 196.9 & 124.3 & 38.1 \\
S. bicolor & 284.4 & 184.2 & 20.3 \\
U. ruziziensis & 319.3 & 105.7 & 17.5 \\
\hline
\end{tabular}

Source: Carvalho et al. (2012). 
of sulfuric acid without external heat source (Nelson \& Sommers, 1996).

The $\mathrm{C}$ of humic fractions of soil organic matter (fulvic acid, humic acid and humin) was determined according to the method described by Mendonça \& Matos (2005). Air-dried fine earth (ADFE) (1 g) was placed with $20 \mathrm{~mL} \mathrm{NaOH} 0.1 \mathrm{~mol} \mathrm{~L}^{-1}$ (ratio 1:20) in a $50 \mathrm{~mL}$ centrifuge tube with a lid. The fulvic acid fraction was obtained from the soluble portion and the alkaline extract humic acid fraction from the precipitate in acid medium after lowering the $\mathrm{pH}$ to between 1 and 1.5. The humin fraction was determined in the remaining precipitate of the tube after centrifugation.

After extraction, the $\mathrm{C}$ of the humic fractions was quantified by $\mathrm{C}$ oxidation with potassium dichromate and titration with ferrous ammonium sulfate with external heating under reflux (Nelson \& Sommers, 1996). The ratio C humic acid/fulvic acid (HA-C/FA-C) was also calculated.

The labile C (LC) content was determined by sample oxidation with $0.033 \mathrm{~mol} \mathrm{~L}^{-1}$ potassium permanganate and reading the extracts in a spectrophotometer at $565 \mathrm{~nm}$ (Mendonça \& Matos, 2005).

The physical particle size of organic matter was also fractionated as described by Cambardella \& Elliott (1992), with adjustments in sample weight (Bayer et al., 2004; Bongiovanni \& Lobartini, 2006). In $250 \mathrm{~mL}$ containers, $20 \mathrm{~g}$ ADFE was mixed with $70 \mathrm{~mL}$ of $5 \mathrm{~g} \mathrm{~L}^{-1}$ sodium hexametaphosphate. The mixture was stirred for $15 \mathrm{~h}$ at $130 \mathrm{rpm}$ on a horizontal shaker. Next, the suspension was sieved $(<53 \mu \mathrm{m})$ with a water jet. The material retained on the sieve consisting of particulate organic matter $(>53 \mu \mathrm{m})$ was dried at $45^{\circ} \mathrm{C}$, weighed, ground in a porcelain mortar and analyzed for $\mathrm{C}$ content in the particulate fraction of soil organic matter (POC). After fractionation, POC was determined by wet oxidation, without external heat source (Nelson \& Sommers, 1996). Organic carbon associated with the mineral fraction (MOC) was calculated as the difference between TOC and POC.

\section{Statistical analyses}

The data were subjected to analysis of variance and the means compared by the Tukey test $(\mathrm{p}<0.05)$, using the statistical software package XLSTAT 2011 (Addinsoft, 2011).

\section{RESULTS AND DISCUSSION}

The effects of cover crops and topdressing on C fractions are presented in table 2 . Significant effects were only observed for HA-C and LC in the two soil layers.

Urochloa ruziziensis resulted in greater HA-C accumulation than the leguminous cover plants in the 0.0-0.10 m soil layer. In the same layer, S. bicolor did not differ from the other species. In the $0.10-0.20 \mathrm{~m}$ layer under U. ruziziensis, HA-C accumulation was higher than under $C$. cajan and the other cover crops induced no difference. Lower lignin concentrations under $U$. ruziziensis than legumes (Table 1) may explain the increased HA-C formation in the surface layer $(0.0-0.10 \mathrm{~m})$, due to the faster cycling. Thus, HA-C was produced, although the lignin content was insufficient for humin formation by humification. Canellas et al. (2007) suggested that higher proportions of HA-C indicate improved humus and organic matter quality.

Carvalho et al. (2012) observed higher yield of corn grown after U. ruziziensis, ascribed by the authors to the rapid decomposition of the plant residues and increased nutrient cycling. Brachiaria species are described in the literature as promising for ground cover due to their drought resistance and ease of management (Machado \& Assis, 2010). Thus, $U$. ruziziensis, rich in hemicellulose and cellulose and with lower lignin concentration produced readily decomposable organic matter, since lignin, which has a more stable structure and is the main precursor of aromatic compounds, favors the formation of more recalcitrant humic substances (Tate III, 1987).

The HA-C/FA-C ratio, proposed by Kononova (1982), was used as quality indicator of humic substances, for expressing the evolution degree of humification, plus the ability to assess $\mathrm{C}$ mobility in the soil. For highly weathered soils, as in the tropics, the HA-C/FA-C ratio is usually less than 1.0 because of the lower condensation and synthesis, rapid and intense mineralization of plant residues, low base content and soil restrictions which limit biological activity in weathered soils (Cerri \& Volkoff, 1988). Fontana et al. (2006) emphasized that low HA-C/FA-C ratios indicate management systems that favor the degradation of more stable fractions or impair their formation.

In the studied systems on an Oxisol, under successive corn crops and different cover species, a ratio of HA-C/FA-C between 0.99 and 1.15 (in the mean 1.07) was calculated, indicating that the soil is in an intermediate process, with intense mineralization of plant residues and ongoing humification. The deposition of crop residues over eight years favored an increase in HA-C concentration, which together with the high annual rainfall, concentrated in the warmer months, intensified biodegradation of the labile SOM fractions, with faster transformation of FA-C into HA-C, mostly under cover plants with lower lignin contents.

With regard to LC, S. bicolor was the species with highest formation of this organic $\mathrm{C}$ fraction in the 0.0-0.10 m layer (Table 2). Nitrogen application to corn increased this fraction of soil organic C. In the 0.10-0.20 m layer, grasses resulted in a higher LC formation than $C$. brasiliensis. The fact that most 
Table 2. Carbon in fulvic acid fractions (FA-C), humic acid (HA-C), humin (HUM-C), carbon humic/fulvic acid ratio (HA-C/FA-C) and labile carbon (LC) in Oxisol under cover plants with (WN) and without (NN) nitrogen fertilization in the layers $0.0-0.10$ and $0.10-0.20 \mathrm{~m}$

\begin{tabular}{|c|c|c|c|c|c|c|c|c|c|c|}
\hline \multirow[t]{2}{*}{ Cover specie } & \multicolumn{2}{|c|}{ FA-C } & \multicolumn{2}{|c|}{ HA-C } & \multicolumn{2}{|c|}{ HUM-C } & \multicolumn{2}{|c|}{ HA-C/FA-C } & \multicolumn{2}{|c|}{ LC } \\
\hline & \multicolumn{10}{|c|}{$0.0-0.10 \mathrm{~m}$} \\
\hline C. cajan & \multicolumn{2}{|c|}{2.82} & \multicolumn{2}{|c|}{$2.91 \mathrm{~b}$} & \multicolumn{2}{|c|}{5.73} & \multicolumn{2}{|c|}{1.03} & \multicolumn{2}{|c|}{$1.70 \mathrm{~b}$} \\
\hline C. brasiliensis & \multicolumn{2}{|c|}{3.03} & & $9 \mathrm{~b}$ & \multicolumn{2}{|c|}{5.92} & \multicolumn{2}{|c|}{0.99} & \multicolumn{2}{|c|}{$1.81 \mathrm{~b}$} \\
\hline S. bicolor & \multicolumn{2}{|c|}{2.86} & & $9 \mathrm{ab}$ & \multicolumn{2}{|c|}{6.49} & \multicolumn{2}{|c|}{1.11} & \multicolumn{2}{|c|}{$2.01 \mathrm{a}$} \\
\hline U. ruziziensis & \multicolumn{2}{|c|}{2.99} & & $3 \mathrm{a}$ & \multicolumn{2}{|c|}{5.70} & \multicolumn{2}{|c|}{1.15} & \multicolumn{2}{|c|}{$1.78 \mathrm{~b}$} \\
\hline \multirow[t]{2}{*}{ Fertilization } & NN & WN & NN & WN & NN & WN & NN & WN & $\mathrm{NN}$ & WN \\
\hline & 2.80 & 3.05 & 3.11 & 3.15 & 5.95 & 5.96 & . & . & $1.73 \mathrm{~B}$ & $1.96 \mathrm{~A}$ \\
\hline $\mathrm{CV}(\%)^{(1)}$ & \multicolumn{2}{|c|}{13.45} & \multicolumn{2}{|c|}{5.80} & \multicolumn{2}{|c|}{14.95} & - & - & \multicolumn{2}{|c|}{5.67} \\
\hline \multirow[t]{2}{*}{ CV $(\%)^{(2)}$} & \multicolumn{2}{|c|}{13.42} & \multicolumn{2}{|c|}{8.76} & \multicolumn{2}{|c|}{18.16} & - & - & \multicolumn{2}{|c|}{8.90} \\
\hline & & & & & & $0 \mathrm{~m}$ & & & & \\
\hline C. cajan & & & & & & & & & & $\mathrm{ab}$ \\
\hline C. brasiliensis & & & & $3 a b$ & & & & & & \\
\hline S. bicolor & & & & $5 \mathrm{ab}$ & & & & & & \\
\hline U. ruziziensis & & & & & & & & & & \\
\hline Fertilization & $\mathrm{NN}$ & WN & $\mathrm{NN}$ & $\mathrm{WN}$ & NN & $\mathrm{WN}$ & $\mathrm{NN}$ & WN & $\mathrm{NN}$ & WN \\
\hline & 2.64 & 2.66 & 2.85 & 2.89 & 5.49 & 5.83 & - & - & 1.63 & 1.68 \\
\hline CV $(\%)^{(1)}$ & & & & & & & & & & .24 \\
\hline CV $(\%)^{(2)}$ & & & & & & & & & & .55 \\
\hline
\end{tabular}

Means followed by the same letter, lowercase in the column and uppercase in a row, do not differ by the Tukey test at $5 \%$.

(1) Coefficient of variation related to cover crops. ${ }^{(2)}$ Coefficient of variation of the effect of fertilization.

cover crops induced higher LC levels in the $0.10-0.20 \mathrm{~m}$ layer was probably related to the high $\mathrm{C}$ input by roots that remain in the soil in deeper layers with more pronounced root decomposition. Kliemann et al. (2006) evaluated the decomposition rate of some grasses and legumes in an Oxisol, and concluded that among the grasses evaluated, $80 \%$ of the S. bicolor straw had already been decomposed after 150 days, while the relative mass loss of $U$. ruziziensis was $56 \%$, and the biomass loss of legume $C$. cajan residues was intermediate $(65 \%)$.

In the 0.0-0.10 m layer, no effects of cover crops and topdressing on TOC were detected (Table 3). However, in the same layer, these effects on POC and MOC levels were confirmed, demonstrating the sensitivity of the $\mathrm{C}$ fractions in response to soil management effects.

The use of $U$. ruziziensis associated with $\mathrm{N}$ topdressing in corn induced greater POC accumulation than in the soil under the other cover crops in the 0.0-0.10 m layer. Similar results were obtained for the MOC content.

In the soil under C. cajan, MOC contents were lower than under $U$. ruziziensis. and $C$. brasiliensis, when no $\mathrm{N}$ was topdressed. On the other hand, $\mathrm{N}$ topdressed on $U$. ruziziensis resulted in the lowest MOC levels. Therefore, $\mathrm{N}$ fertilization increased the MOC contents in the soil under S. bicolor and legumes, but promoted reduction under U. ruziziensis. Nitrogen fertilization in the plots with $U$. ruziziensis, which has a low C:N ratio and lower lignin content (Carvalho et al., 2011; 2012) than the other cover crops (Table 1), reduced MOC formation.

In the 0.10-0.20 m layer, U. ruziziensis and $C$. brasiliensis induced greater TOC accumulation than $S$. bicolor, while TOC contents under C. cajan were similar to those under the other cover crops (Table 3). Carmo et al. (2012) found that differences in TOC between soil under corn in monoculture or intercropped with different Brachiaria species were restricted to the 0.0-0.10 m layer, and were attributed to the high amounts of fine roots in the surface and the short management period under no-tillage.

The abundant root system of $U$. ruziziensis may have favored the higher TOC accumulation below a depth of $10 \mathrm{~cm}$. In addition, the root system of $C$. brasiliensis and $C$. cajan is deeper and makes these cover crops more drought-resistant (Burle et al., 2006), and particularly well-suited for the soil and climatic conditions of the Cerrado, contributing to increase $\mathrm{C}$ accumulation in the soil.

Differences between the cover crops were only observed in the POC and MOC levels in the $0.10-0.20 \mathrm{~m}$ layer when $\mathrm{N}$ was topdressed. The soils under $C$. brasiliensis and $S$. bicolor contained higher POC levels than under the other species, demonstrating 
the ability of these plants to accumulate more readily decomposable $\mathrm{C}$ in the $0.10-0.20 \mathrm{~m}$ layer. Instead, these species promoted lower MOC levels in the soil than $U$. ruziziensis and C. cajan.

In general, since POC accumulation is associated with recent plant material input and soil sampling occurred at the end of the crop cycle, the data of this study show that the proportion of the stable and humified form of soil C in this soil was greater (MOC). According to Rossi et al. (2012), this is usually observed in native Cerrado areas, where there is no plowing or other soil disturbance, resulting in high SOM stabilization in the mineral fraction. In this study, under no tillage, the deposition of plant residues of cover crops and corn for eight years increased the MOC concentrations in both soil layers, especially for $C$. cajan. Also, the high lignin concentration in C. cajan favored an accumulation of more stable $\mathrm{C}$ in the soil, which is an important mechanism for $\mathrm{C}$ maintenance or "sequestration" in the soil.

The $\mathrm{C}$ proportions in the fractions in relation to TOC are presented in table 4 . The values are within

Table 3. Total organic carbon (TOC), particulate organic carbon (POC) and mineral organic carbon (MOC) in Oxisol under cover plants with (WN) and without (NN) $\mathrm{N}$ fertilization

\begin{tabular}{|c|c|c|c|c|c|}
\hline \multirow{2}{*}{ Cover specie } & \multirow{2}{*}{ TOC } & \multicolumn{2}{|c|}{ POC } & \multicolumn{2}{|c|}{ MOC } \\
\hline & & NN & WN & NN & WN \\
\hline & \multirow{2}{*}{\multicolumn{5}{|c|}{$\begin{array}{c}\mathrm{g} \mathrm{kg}^{-1} \longrightarrow \\
0.0-0.10 \mathrm{~m}\end{array}$}} \\
\hline & & & & & \\
\hline C. cajan & 18.31 & $6.94 \mathrm{aA}$ & $2.56 \mathrm{bB}$ & $10.56 \mathrm{bB}$ & $16.57 \mathrm{aA}$ \\
\hline C. brasiliensis & 19.22 & $5.06 \mathrm{aA}$ & $4.22 \mathrm{bA}$ & $13.99 \mathrm{aA}$ & $15.17 \mathrm{aA}$ \\
\hline S. bicolor & 18.73 & $5.25 \mathrm{aA}$ & $4.15 \mathrm{bA}$ & $12.96 \mathrm{abA}$ & $15.08 \mathrm{aA}$ \\
\hline U. ruziziensis & 19.72 & $5.40 \mathrm{aB}$ & $9.22 \mathrm{aA}$ & $15.35 \mathrm{aA}$ & $9.47 \mathrm{bB}$ \\
\hline CV $(\%)^{(1)}$ & 6.50 & \multicolumn{2}{|c|}{19.70} & \multicolumn{2}{|c|}{9.01} \\
\hline \multirow[t]{2}{*}{$\mathrm{CV}(\%)^{(2)}$} & 7.09 & & & & \\
\hline & & & $0.10-0.20 \mathrm{~m}$ & & \\
\hline C. cajan & $17.59 \mathrm{ab}$ & $4.06 \mathrm{aA}$ & $2.59 \mathrm{bA}$ & $13.00 \mathrm{aB}$ & $15.53 \mathrm{aA}$ \\
\hline C. brasiliensis & $18.40 \mathrm{a}$ & $4.50 \mathrm{aB}$ & $6.68 \mathrm{aA}$ & $13.83 \mathrm{aA}$ & $11.80 \mathrm{bA}$ \\
\hline S. bicolor & $17.27 \mathrm{~b}$ & $3.67 \mathrm{aB}$ & $6.80 \mathrm{aA}$ & $13.63 \mathrm{aA}$ & $10.43 \mathrm{bB}$ \\
\hline U. ruziziensis & $18.45 \mathrm{a}$ & $5.60 \mathrm{aA}$ & $2.60 \mathrm{bB}$ & $12.80 \mathrm{aB}$ & $15.90 \mathrm{aA}$ \\
\hline CV $(\%)^{(1)}$ & 3.06 & \multicolumn{2}{|c|}{24.70} & \multicolumn{2}{|c|}{8.85} \\
\hline CV $(\%)^{(2)}$ & 5.03 & \multicolumn{2}{|c|}{19.08} & \multicolumn{2}{|c|}{9.52} \\
\hline
\end{tabular}

Means followed by the same letter, lowercase in the column and uppercase in a row for each property, do not differ by the Tukey test at $5 \%$. ${ }^{(1)}$ Coefficient of variation related to cover crops. ${ }^{(2)}$ Coefficient of variation of the effect of fertilization.

Table 4. Carbon relative to the total organic carbon (TOC) of organic carbon fraction of fulvic acids (FA-C), humic acid (HA-C), humin (HUM-C), labile carbon (LC), particulate organic carbon (POC) and associated minerals (MOC) in Oxisol under cover plants with (WN) and without (NN) of $\mathrm{N}$ fertilization

\begin{tabular}{|c|c|c|c|c|c|c|c|c|c|c|c|c|}
\hline \multirow{2}{*}{ Cover specie } & \multicolumn{2}{|c|}{ FA-C } & \multicolumn{2}{|c|}{ HA-C } & \multicolumn{2}{|c|}{ HUM-C } & \multicolumn{2}{|c|}{ LC } & \multicolumn{2}{|c|}{ POC } & \multicolumn{2}{|c|}{ MOC } \\
\hline & NN & WN & NN & WN & NN & WN & NN & WN & NN & WN & NN & WN \\
\hline & \multicolumn{12}{|c|}{$0.0-0.10 \mathrm{~m}$} \\
\hline C. cajan & 16 & 15 & 17 & 15 & 33 & 30 & 10 & 09 & 53 & 20 & 47 & 80 \\
\hline C. brasiliensis & 16 & 16 & 15 & 15 & 31 & 31 & 09 & 10 & 27 & 51 & 73 & 49 \\
\hline S. bicolor & 14 & 17 & 18 & 15 & 35 & 34 & 11 & 11 & 39 & 26 & 61 & 74 \\
\hline \multirow[t]{2}{*}{ U. ruziziensis } & 15 & 16 & 15 & 17 & 29 & 30 & 08 & 10 & 37 & 63 & 63 & 79 \\
\hline & \multicolumn{12}{|c|}{$0.10-0.20 \mathrm{~m}$} \\
\hline C. cajan & 14 & 14 & 14 & 16 & 29 & 31 & 09 & 08 & 21 & 25 & 79 & 75 \\
\hline C. brasiliensis & 16 & 15 & 16 & 16 & 31 & 30 & 09 & 08 & 35 & 37 & 65 & 60 \\
\hline S. bicolor & 15 & 15 & 18 & 15 & 33 & 36 & 10 & 10 & 31 & 65 & 69 & 35 \\
\hline U. ruziziensis & 16 & 15 & 17 & 17 & 32 & 33 & 09 & 10 & 21 & 41 & 37 & 59 \\
\hline
\end{tabular}


the range normally found for tropical soils, as in these Oxisols predominant in the Cerrado (Figueiredo et al., 2013). The humic substances contained, in the mean, $63 \%$ TOC, with a higher proportion in the HUM-C, followed by HA-C and FA-C. For being less stable and more easily polymerized or mineralized, the residual levels of FA-C and HA-C fractions may decrease in the soil (Fontana et al., 2006). These $\mathrm{C}$ proportions in the humic substances in relation to TOC were little affected by $\mathrm{N}$ topdressing.

The percentage of LC compared to TOC varied from 8 to $11 \%$, with little variation among plant species and $\mathrm{N}$ fertilization in corn. The highest variations in the $\mathrm{C}$ proportions in relation to TOC were observed in the POC fraction ranging from 21 and $63 \%$, which is within a range proposed by Cambardella \& Elliott (1992) and Bayer et al. (2002). The results indicate that the SOM fraction is sensitive to the crop succession and $\mathrm{N}$ fertilization, even after only eight years of no-tillage management. The TOC proportions in the POC and MOC fractions demonstrate the importance of accumulation and quality of cover crop residues and fertilization for the formation of these fractions in Cerrado soil. The high participation of MOC in TOC shows the strong interaction of organic matter with $\mathrm{Fe}$ and $\mathrm{Al}$ oxides and kaolinite predominant in the Cerrado soils, as also reported by Bayer et al. (2002) for soils in the subtropical region and by Figueiredo et al. (2013) for soils of the Brazilian Cerrado.

\section{CONCLUSIONS}

1. In general, Urochloa ruziziensis promoted highest carbon levels, in particular of the humic acid fractions and particulate organic carbon, which are quality indicators of soil organic matter.

2. Topdressing had little influence on the content of recalcitrant organic matter, but increased levels of labile organic carbon and changed the contents of particulate organic carbon associated to clay minerals.

3 . The carbon of humic substances and organic carbon associated to minerals had greater proportions of total organic carbon and demonstrated the strong interaction of organic matter with $\mathrm{Fe}$ and $\mathrm{Al}$ oxides and kaolinite predominant in the weathered Cerrado soils.

\section{LITERATURE CITED}

ADÁMOLI, J.; MACEDO, J.; AZEVEDO, L.G. \& MADEIRA NETO, J. Caracterização da região dos Cerrados. In: GOEDERT, W.J., ed. Solos dos Cerrados: Tecnologias e estratégias de manejo. São Paulo, Nobel, 1986. p.33-74.

ADDINSOFT. XLSTAT 2011: Statistical Software to MS Excel. New York, Addinsoft, 2011.
ALVES, B.J.R.; URQUIAGA, S.; AITA, C.; BODDEY, R.M.; JANTALIA, C.P. \& CAMARGO, F.A.O. Manejo de sistemas agrícolas: Impacto no sequestro de $\mathrm{C}$ e nas emissões de gases de efeito estufa. Porto Alegre, Genesis, 2006. $216 \mathrm{p}$.

BAYER, C.; MIELNICZUK, J.; MATIN-NETO, L. \& ERNANI, P.R. Stocks and humification degree of organic matter fractions as affected by no-tillage on a subtropical soil. Plant Soil, 238:133-140, 2002.

BAYER, C.; MATIN-NETO, L.; MIELNICZUK, J. \& PAVINATO, A. Armazenamento de carbono em frações lábeis da matéria orgânica de um Latossolo Vermelho sob plantio direto. Pesq. Agropec. Bras., 39:677-683, 2004.

BONGIOVANNI, M.D. \& LOBARTINI, J.C. Particulate organic matter, carbohydrate, humic acid contents in soil macro and micro aggregates as affected by cultivation. Geoderma, 136:660-665, 2006.

BURLE, M.L.; CARVALHO, A.M.; AMABILE, R.F. \& PEREIRA, J. Caracterização de espécies de adubo verde. In: CARVALHO, A.M. \& AMABILE, R.F., eds. Cerrado: Adubação verde. Planaltina, Embrapa Cerrados, 2006. p.71-142.

CAMBARDELLA, C.A. \& ELLIOTT, E.T. Particulate soil organic matter changes across a grassland cultivation sequence. Soil Sci. Soc. Am. J., 56:777-783, 1992.

CANELLAS, L.P.; BALDOTTO, M.A.; BUSATO, J.G.; MARCIANO, C.R.; MENEZES, S.C.; SILVA, N.M.; RUMJANEK, V.M.; VELLOSO, A.C.X.; SIMÕES, M.L. \& MARTIN-NETO, L. Estoque e qualidade da matéria orgânica de um solo cultivado com cana-de-açúcar por longo tempo. R. Bras. Ci. Solo, 31:331-340, 2007.

CARMO, F.F.; FIGUEIREDO, C.C.; RAMOS, M.L.G.; VIVALDI, L.J. \& ARAÚJO, L.G. Frações granulométricas da matéria orgânica em Latossolo sob plantio direto com gramíneas. Biosci. J., 28:420-431, 2012.

CARVAlHO, A.M.; COELHO, M.C.; DANTAS, R.A.; FONSECA, O.P.; GUIMARÃES JÚNIOR, R. \& FIGUEIREDO, C.C. Chemical composition of cover plants and its effect on maize yield in no-tillage systems in the Brazilian savanna. Crop Past. Sci., 63:1075-1081, 2012.

CARVALHO, A.M.; SOUZA, L.L.P.; JÚNIOR, R.G.; ALVES, P.C.A.C. \& VIVALDI, L.J. Cover plants that present potential use in integrated systems in the Cerrado region. Pesq. Agropec. Bras., 36:1200-1205, 2011.

CARVAlHO, A.M. \& AMABILE, R.F. Cerrado: Adubação verde. In: CARVALHO, A.M. \& AMABILE, R.F., eds. Plantas condicionadoras de solo: Interações edafoclimáticas, uso e manejo. Planaltina, Embrapa Cerrados, 2006. p.143-170.

CERRI, C.C. \& VOLKOFF, B. Matéria orgânica de três solos dos campos inundáveis da Ilha de Marajó (PA). R. Bras. Ci. Solo, 12:93-100, 1988.

EMPRESA BRASILEIRA DE PESQUISA AGROPECUÁRIA . EMBRAPA. Centro Nacional de Pesquisa de Solos. Manual de métodos de análise de solos. 2.ed. Rio de Janeiro, 1997. 212p. 
FIGUEIREDO, C.C.; RESCK, D.V.S. \& CARNEIRO, M.A.C. Labile and stable fractions of soil organic matter under management systems and native Cerrado. R. Bras. Ci. Solo, 34:907-916, 2010.

FIGUEIREDO, C.C.; RESCK, D.V.S.; CARNEIRO, M.A.C.; RAMOS, M.L.G. \& SÁ, J.C.M. Stratification ratio of organic matter pools influenced by management systems in a weathered Oxisol from a tropical agro-ecoregion in Brazil. Soil Res., 51:133-141, 2013.

FONTANA, A.; PEREIRA, M.G.; LOSS, A.; CUNHA, T.J.F. \& SALTON, J.C. Atributos de fertilidade e frações húmicas de um Latossolo Vermelho no Cerrado. Pesq. Agropec. Bras., 41:847-853, 2006.

KONONOVA, M.M. Materia orgánica del suelo: Su naturaleza, propiedades y métodos de investigación. Barcelona, Oikostau, 1982. 364p.

KLIEMANN, H.J.; BRAZ, A.J.P.B. \& SILVEIRA, P.M. Taxas de decomposição de resíduos de espécies de cobertura em Latossolo Vermelho distroférrico. Pesq. Agropec. Trop., $36: 21-28,2006$.

LOSS, A.; PEREIRA, M.G.; FERREIRA, E.P.; SANTOS, L.L.; BEUTLER, S.J. \& FERRAZ-JUNIOR, A.S.L. Frações oxidáveis do carbono orgânico do solo em sistemas de aleias sob Argissolo Vermelho-Amarelo. R. Bras. Ci. Solo, 33:867-874, 2009.

MACHADO, L.A.Z. \& ASSIS, P.G.G. Produção de palha e forragem por espécies anuais e perenes em sucessão à soja. Pesq. Agropec. Bras., 45:415-422, 2010.

MENDONÇA, E.S. \& MATOS, E.S. Matéria orgânica do solo: Métodos de análises. Viçosa, MG, Universidade Federal de Viçosa, 2005. 107p.
NELSON, D.W. \& SOMMERS, L.E. Total carbon, organic carbon, and organic matter. In: BLACK, C.A., ed. Methods of soil analysis: Chemical methods. Madison, Soil Science of America/American Society of Agronomy, 1996. Part 3, p.961-1010.

REATTO, A.; BRUAND, A.; MARTINS, E.S.; MULLER, F.; SILVA, E.M.; CARVALHO JÚNIOR, O.A.; BROSSARD, M. \& RICHARD, G. Development and origin of the microgranular structure in Latosols of the Brazilian Central Plateau: Significance of texture, mineralogy, and biological activity. Catena, 76:122-134, 2009.

ROBERTSON, J.B. \& van SOEST, P.J. The detergent system of analysis and its application to human's foods. In: JAMES, H.P.T. \& THEANDER, O., eds. The analysis of dietary fiber in food. New York, Marcel Dekker, 1981. p.123-158.

ROSSI, C.Q.; PEREIRA, M.G.; GIÁCOMO, S.G.; BETTA, M. \& POLIDORO, J.C. Frações lábeis da matéria orgânica em sistema de cultivo com palha de braquiária e sorgo. R. Ci. Agron., 43:38-46, 2012.

SALTON, J.C.; MIELNICZUK, J.; BAYER, C.; FABRÍCIO, A.C.; MACEDO, M.C.M. \& BROCH, D.L. Teor e dinâmica do carbono no solo em sistemas de integração lavourapecuária. Pesq. Agropec. Bras., 46:1349-1356, 2011.

TATE III, R.L. Humic and fulvic acids: formation and decomposition. In: TATE III, R.L., ed. Soil organic matter: Biological and ecological effects. New York, John Wiley \& Sons, 1987. p.147-164.

VERGUTZ, L.; NOVAIS, R.F.; SILVA, I.R.; BARROS, N.F.; NUNES, T.N. \& PIAU, A.A.M. Mudanças na matéria orgânica do solo causadas pelo tempo de adoção de um sistema agrossilvopastoril com eucalipto. R. Bras. Ci. Solo, 34:43-57, 2010. 